\title{
The 2007 recipient of the Brady Medal: Professor John W. Murray
}

\author{
MALCOLM B. HART \& CHRISTOPHER W. SMART \\ School of Earth, Ocean \& Environmental Sciences, University of Plymouth, Drake Circus, Plymouth PL4 8AA, UK \\ (e-mail: mhart@plymouth.ac.uk)
}

The first recipient of the Brady Medal, which was presented on 7 November 2007, is Professor John W. Murray of the National Oceanographic Centre, University of Southampton. The awardee is singularly appropriate as Henry Bowman Brady studied (mainly benthic) foraminifera. John was also one of the speakers at the first open meeting of the then British Micropalaeontological Group when it met at Sheffield University in March 1971 under the Chairmanship of Professor Leslie R. Moore (one of the founding fathers of the TMS). Other speakers on that day included Charles Downie, Alan Higgins, Keith Gueinn, Eric Robinson, Ron Austin, Geoff Warrington, Gerry Orbell, Malcolm Hart, Geoff Eaton and Mike Boulter.

John was born in London in 1937 and was evacuated to the north of England during the Second World War. The family returned south to Worthing in 1953. As a teenager John asked his parents for a biological microscope with which he developed his interest in microscopy (both biological and geological). In 1956 he enrolled on the BSc (Hons) Geology programme at Imperial College (London University) in the first year of which he was introduced to foraminifera by David Carter, who also supervised a final year project on the planktonic foraminifera recovered from one of the early boreholes for the Channel Tunnel Site Investigation. For his $\mathrm{PhD}$ research (again supervised by David Carter) John elected to study the benthic foraminifera of Christchurch Harbour in Dorset. This involved regular sampling of the harbour sediments, staining the living foraminifera and taking measurements of temperature, salinity, dissolved oxygen and $\mathrm{pH}$. It was this detailed work on the ecology of the fauna that began his life-long passion for the smaller benthic foraminifera and their ecology. This work was extended in 1961-1962 when John obtained a post-doctoral position at the laboratories of the Marine Biological Association in Plymouth. This allowed him to study the benthic foraminifera of Plymouth Sound and the English Channel, both areas made famous by the pioneering work of Fortescue Millett and Edward Heron-Allen. His position in Plymouth was ended prematurely by the offer of a lectureship at the University of Bristol where he remained until 1975 .

While he was a lecturer at Bristol there were, at least, three significant events that were to influence his future research. The first of these was a sampling trip to the United Arab Emirates in the Middle East. This introduced John to the very different assemblages of foraminifera found in the Persian Gulf and the hypersaline lagoons that fringe its shores. The second was the award of the 'John Murray Travelling Studentship' by The Royal Society which allowed him to visit Woods Hole Oceanographic Institution in the USA and sample some of the important near-shore environments in that area. The third, and perhaps most significant, event was becoming involved in marine work and the seafloor mapping in the English Channel with Prof. W. F. Whittard and, after his death, Doug Hamilton. This interest in offshore sediments, and the foraminifera they contained, has continued all around the UK (and beyond), including participation on DSDP Leg 81 in the North Atlantic Ocean in 1981. The work in the English Channel led to a developing interest in the Tertiary foraminifera and the Palaeogene successions of the Isle of Wight and the wider Anglo-Paris Basin.

It was in the late 1960s that scanning electron microscopes began appearing in some British universities and this enabled John to produce his Atlas of British Recent Foraminiferids in 1971: almost certainly one of the first books to be illustrated almost entirely with beautiful SEM photographs. For those fortunate enough to own a copy, this remains a valuable source of information to this day. This was followed, two years later (1973), by the publication of the first of his landmark books on the ecology of benthic foraminifera (Distribution and Ecology of Living Benthic Foraminiferids).

It was during his stay in Bristol that he and his father designed and built a seafloor sampler that - unlike most 'grabs' available at that time - retained the fine surface sediment (and the water) in a sealed compartment. With John's permission, the workshops in the University of Plymouth fabricated the sampler for us to use in our continuing work in Plymouth Sound. Our 'Murray Grab' as it is affectionately known, remains in use to this day. In 2007 it was being successfully deployed from the stern of the Plymouth Marine Laboratory boat in Plymouth Sound, allowing MRes student Tracy Aze to collect samples which still arrive on deck in the sealed container. Unfortunately the number of living foraminifera in Plymouth Sound has reduced markedly since John collected his samples, the direct result of the clean-up of the waters in the Sound.

In 1975 John moved to the University of Exeter as Professor of Geology and Head of Department. This was a small, friendly department set in an idyllic campus on the old Streatham Estate on the hills above Exeter. John's office, we recall, was set in the corner of the building with a beautiful view over the park and the City of Exeter. While located in Exeter he began work on the foraminifera of the Exe Estuary and contributed a chapter to the Essays on the Exe Estuary, published by the Devonshire Association in 1980. It was also during his time at Exeter University that John, with D. Graham Jenkins, edited the first edition of the Stratigraphical Atlas of Fossil Foraminifera which appeared in 1981 (second edition in 1989) and which was followed in 1985 by the Atlas of Invertebrate Macrofossils published by Longman for The Palaeontological Association.

In 1988/89 The University Grants Committee (UGC) undertook what was to be the first of a series of 'subject reviews'. Geology was first into this process and, after the experience gained, it proved to be the last! The Geology Department at 
Exeter was deemed to be too small (despite giving students a good educational experience) and, like comparable departments in Hull, Swansea and Newcastle, was closed. John moved to the University of Southampton and, following the relocation of the Institute of Oceanographic Sciences to the new waterfront site near Ocean Village in Southampton, became part of the Southampton Oceanography Centre (now National Oceanographic Centre, Southampton). Following his retirement, John is Emeritus Professor at the NOC.

For a few years John led a successful MSc in Micropalaeontology but this foundered for a number of reasons beyond his control. More enduring was his developing work on agglutinated foraminifera and a scientific partnership with Elizabeth Alve of the University of Oslo. This ongoing work has generated many significant publications, some of which involved material from a new location, the Hamble Estuary near Southampton.

Throughout his career John has taught palaeontology, micropalaeontology and stratigraphy to a great many students (including Christopher Smart and Andrew Hart) and supervised over $20 \mathrm{PhD}$ students (including CWS). He has produced almost 200 scientific papers, articles and book chapters and edited/ written several major books. His latest book on the Ecology and Applications of Benthic Foraminifera represents a culmination of his years of devotion to benthic foraminifera and their ecology. Throughout this time he has served several scientific societies in a variety of capacities; this service to the community being recognized by the award of The Coke Medal by The Geological Society in 2007. His scientific achievements have been recognized by the 2001 Joseph A. Cushman Award of the Cushman Foundation, the award of an Honorary Membership by The Micropalaeontological Society in 2005 and by the award of the Brady Medal in 2007.

John has a global following of those interested in all of his publications on benthic foraminifera and a wide circle of friends and colleagues; both of us are honoured and delighted to have been in both categories for a good many years.

\section{SERVICE TO EXTERNAL COMMUNITY \& AWARDS}

1957 Murchison Medal, Imperial College, London

1958 University $\quad$ Watts Medal, Imperial College, London University

1959 Clement le Neve Foster Prize, Imperial College, London University

1961 Marshall Scholarship, Imperial College, London University

1962 Sir John Murray Travelling Studentship, The Royal Society

1972-1974 Secretary, Foraminifera Group, The Micropalaeontological Society

1974 Huxley Medal, Imperial College, London University

1974-1979 Editor, Palaeontology
1978-1980 Chairman, The Micropalaeontological Society

1981 Wollaston Fund, The Geological Society of London

1989-1992 Honorary Secretary, The Geological Society of London

1990-1992 President, The Palaeontological Association 1991 T.N. George Medal, Glasgow Geological Society

1993-1997 Editor, Journal of Micropalaeontology

1997-2003 Earth Resources Committee, The Royal Society, London

2001 J.A. Cushman Award, Cushman Foundation, Washington DC, USA

2003-on Distinguished Visitor, The Natural History Museum, London

2005 Honorary Membership, The Micropalaeontological Society

2006 Honorary Membership, The Palaeontological Association

2007 Coke Medal, The Geological Society of London 2007 Brady Medal, The Micropalaeontological Society

\section{SELECTED LANDMARK PUBLICATIONS}

Murray, J.W. 1963. Ecological experiments on Foraminiferida. Journal of the Marine Biological Association of the United Kingdom, 43: 621-642.

Murray, J.W. 1965. On the foraminifera of the Plymouth region. Journal of the Marine Biological Association of the United Kingdom, 45: 481-505.

Murray, J.W. 1968a. The living Foraminiferida of Christchurch Harbour, England. Micropaleontology, 14: 83-96.

Murray, J.W. 1968b. Living foraminifers of lagoons and estuaries. Micropaleontology, 14: 435-455.

Murray, J.W. 1971. An Atlas of British Recent Foraminiferids. Heinemann Educational Books, London, 244pp.

Murray, J.W. \& Wright, C.A. 1974. Palaeogene foraminiferids and palaeoecology, Hampshire and Paris basins and the English Channel. Special Papers in Palaeontology, 14: 129pp.

Murray, J.W. 1973. Distribution and Ecology of Living Benthic Foraminiferids. Heinemann Educational Books, London, 274pp.

Murray, J.W. 1980. The foraminifera of the Exe Estuary. In: Boalch, G.T. (Ed.), Essays on the Exe Estuary. The Devonshire Association for the Advancement Of Science, Literature and Art, Special Volume, 2: 89-115.

Murray, W.G. \& Murray, J.W. 1980. A device for obtaining representative samples from the sediment-water interface. Marine Geology, 76: 313-317.

Murray, J.W. (Ed.) 1985. Atlas of Invertebrate Macrofossils. Longman Group Ltd, Harlow, 241pp.

Jenkins, D.G. \& Murray, J.W. (Eds) 1989. Stratigraphical Atlas of Fossil Foraminifera, (2nd edn) Ellis Horwood Ltd, Chichester, 592pp.

Murray, J.W. 1991. Ecology and Palaeoecology of Benthic Foraminifera. Longman Group UK Limited, Harlow, 397pp.

Murray, J.W. \& Alve, E. 1999. Natural dissolution of shallow water benthic foraminifera: taphonomic effects on the palaeoecological record. Palaeogeography, Palaeoclimatology, Palaeoecology, 146: 195-206.

Murray, J.W. 2001. The niche of benthic foraminifera, critical thresholds and proxies. Marine Micropaleontology, 41: 1-7.

Murray, J.W. 2006. Ecology and Applications of Benthic Foraminifera. Cambridge University Press, Cambridge, 426pp. 